\title{
Analisa Sisa Material Konstruksi Pada Kegiatan Pembangunan Mesjid
}

\author{
Annisaa Dwiretnani ${ }^{1}$, Kiki Rizky Amalia ${ }^{2}$, Alfiando Wijaya A. K ${ }^{3}$ \\ ${ }^{1,2}$ Dosen Program Studi Teknik Sipil Universitas Batanghari \\ ${ }^{3}$ Mahasiswa Program Studi Teknik Sipil Universitas Batanghari \\ Correspondence email: annisaa.dwiretnani@gmail.com
}

\begin{abstract}
Abstrak. Sisa material konstruksi merupakan salah satu masalah serius pada pelaksanaan proyek. Adanya usaha meminimalkan hal tersebut turut membantu mengurangi dampak negatif terhadap lingkungan. Pada penelitian ini difokuskan pada kajian sisa material konstruksi untuk pekerjaan balok dan kolom pada Kegiatan Pembangunan Mesjid Komplek Perkantoran Walikota Jambi (Lanjutan). Penelitian dilakukan dengan menganalisa persentase sisa material konstruksi, persentase terbesar sisa material konstruksi dan faktor-faktor apa saja yang menjadi penyebab terjadinya sisa material konstruksi pekerjaan balok dan kolom pada Kegiatan Pembangunan Mesjid Komplek Perkantoran Walikota Jambi (Lanjutan). Persentase sisa material konstruksi pekerjaan balok dan kolom terbanyak adalah pasir, yakni sebanyak 33,33\% atau setara dengan $2 \mathrm{~m}^{3}$.
\end{abstract}

Kata Kunci: Sisa Material Konstruksi, Balok, Kolom

\section{PENDAHULUAN}

Konstruksi merupakan suatu kegiatan membangun sarana maupun prasarana. Dalam bidang teknik sipil, sebuah konstruksi didefinisikan sebagai objek keseluruhan bangunan yang terdiri dari bagian-bagian struktur. Misal, konstruksi bangunan adalah bentuk/bangun secara keseluruhan dari struktur bangunan. Contoh lainnya, yaitu konstruksi jalan raya, konstruksi jembatan, konstruksi bendungan dan lain-lain.

Pada tahap pelaksanaan konstruksi, penggunaan material di lapangan sering menimbulkan sisa yang cukup besar. Sisa material konstruksi (construction waste) merupakan sesuatu yang sifatnya berlebih dari yang disyaratkan/direncanakan, baik berupa hasil pekerjaan maupun material konstruksi yang tersisa/tercecer/rusak dan tidak dapat digunakan lagi sebagaimana fungsinya.

Sisa material konstruksi merupakan salah satu masalah serius pada pelaksanaan proyek. Adanya usaha meminimalkan hal tersebut turut membantu mengurangi dampak negatif terhadap lingkungan. Oleh karena itu, perlu dilakukan perhitungan yang tepat dalam menentukan jumlah kebutuhan material proyek dan langkah evaluasi terhadap penggunaannya.

Perkantoran Walikota Jambi merupakan kantor kedinasan yang sangat penting terkait peranannya dalam mengembangkan Kota Jambi. Oleh karena itu, segala fasilitas umum yang dibutuhkan oleh pegawai itu sendiri haruslah dipenuhi oleh pemerintah, salah satunya dengan dibangunnya mesjid sebagai tempat beribadah mayoritas pegawai kantor yang beragama Islam. Penelitian ini difokuskan pada kajian sisa material konstruksi untuk pekerjaan balok dan kolom pada Kegiatan Pembangunan Mesjid Komplek Perkantoran Walikota Jambi (Lanjutan).

\section{METODE}

Tahap penelitian merupakan urutan langkah atau tata cara yang dilaksanakan secara sistematis dan logis sesuai dasar teori permasalahan sehingga didapat analisis yang akurat untuk mencapai tujuan penelitian. Adapun tahapan penelitian yang dilakukan adalah sbb:

1. Tahap Persiapan

Pada tahap persiapan, beberapa langkah yang dilakukan adalah merumuskan masalah penelitian, menentukan tujuan penelitian dan melakukan studi pustaka.

2. Tahap Pengumpulan Data

Pada tahap pengumpulan data, beberapa langkah yang dilakukan adalah mengumpulkan data primer dan data sekunder yang dibutuhkan. Data tersebut berupa jenis dan volume material pekerjaan balok dan kolom, kebutuhan material konstruksi di lapangan, volume sisa material konstruksi (construction waste) yang dihasilkan serta faktorfaktor apa saja yang menjadi penyebab terjadinya sisa material konstruksi pekerjaan balok dan kolom pada Kegiatan Pembangunan Mesjid Komplek Perkantoran Walikota Jambi (Lanjutan).

3. Tahap Analisis Data

Pada tahap analisis data, beberapa langkah yang dilakukan adalah sebagai berikut:

a. Menghitung kebutuhan material konstruksi pekerjaan balok dan kolom.

b. Menghitung sisa material konstruksi pekerjaan balok dan kolom.

c. Menghitung persentase terbesar sisa material konstruksi pekerjaan balok dan kolom. 
d. Mencari faktor-faktor apa saja yang menjadi penyebab terjadinya sisa material konstruksi pekerjaan balok dan kolom.

4. Tahap Pembahasan

Pada tahap pembahasan, langkah yang dilakukan adalah menganalisa hasil penelitian terkait persentase sisa material konstruksi, persentase terbesar sisa material konstruksi dan faktor-faktor apa saja yang menjadi penyebab terjadinya sisa material konstruksi pekerjaan balok dan kolom pada Kegiatan Pembangunan Mesjid Komplek Perkantoran Walikota Jambi (Lanjutan) sehingga dapat ditarik suatu kesimpulan.

Di bawah ini adalah bagan alir atau kerangka dari seluruh metodologi penelitian yang dilakukan:

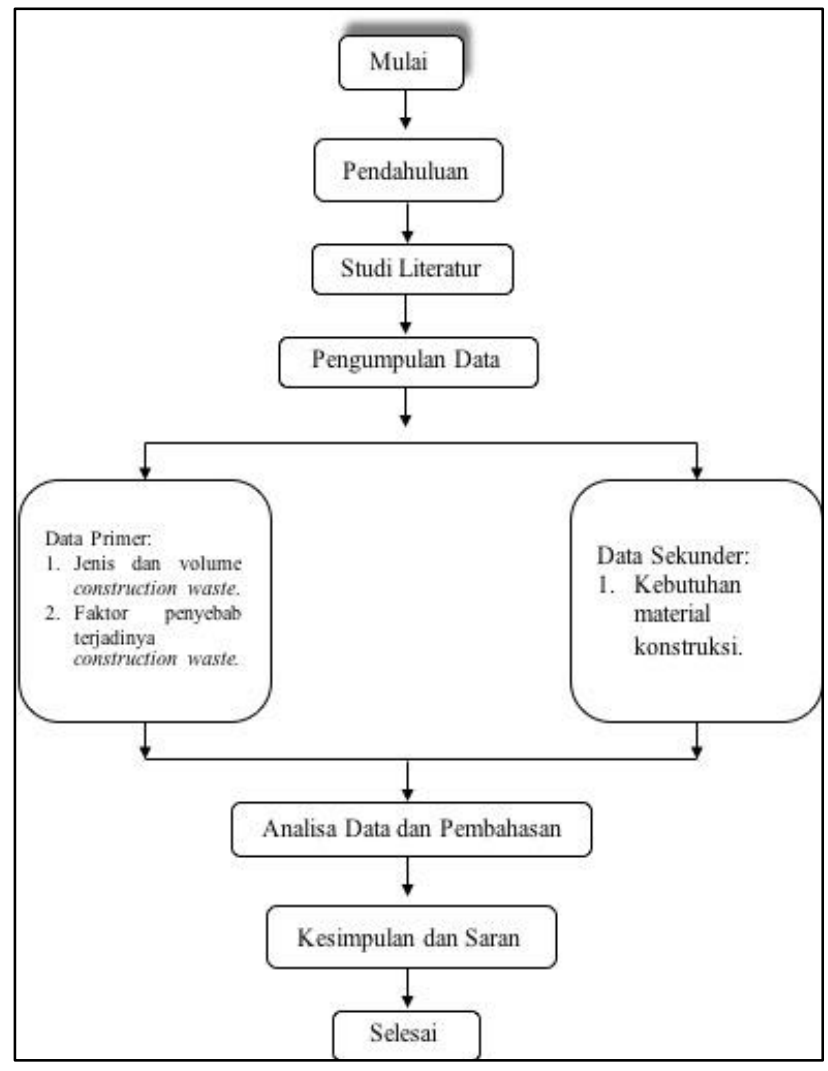

Sumber: Data Olahan (2019)

Gambar 1. Bagan Alir Penelitian

\section{HASIL DAN PEMBAHASAN}

Adapun rangkaian proses analisa data primer (berupa hasil observasi lapangan dan wawancara langsung dengan pihak-pihak terkait) dan data sekunder (berupa gambar asbuilt drawing) mengenai persentase sisa material konstruksi, persentase terbesar sisa material konstruksi dan faktor-faktor apa saja yang menjadi penyebab terjadinya sisa material konstruksi pekerjaan balok dan kolom pada Kegiatan Pembangunan Mesjid Komplek Perkantoran Walikota Jambi (Lanjutan) adalah sebagai berikut:

a. Perhitungan Volume Balok
a. Pekerjaan Balok Pinggang
b. Pekerjaan Balok DAK Kubah
c. Pekerjaan Balok DAK Menara
d. Pekerjaan Ring Balok

b. Perhitungan Volume Kolom
a. Pekerjaan Kolom Praktis Lantai I
b. Pekerjaan Kolom Praktis Lantai II
c. Pekerjaan Kolom 20/20
c. Perhitungan Volume Besi
1. Kolom Praktis (Tulangan Pokok)
2. Kolom 20/20 (Tulangan Pokok)
3. Kolom Praktis (Tulangan Sengkang)
4. Kolom 20/20 (Tulangan Sengkang)
5. Balok Pinggang (Tulangan Pokok) 
6. Balok DAK Kubah (Tulangan Pokok)

7. Balok DAK Menara (Tulangan Pokok)

8. Ring Balok (Tulangan Pokok)

9. Balok Pinggang (Tulangan Sengkang)

10.Balok DAK Kubah (Tulangan Sengkang)

11.Balok DAK Menara (Tulangan Sengkang)

12.Ring Balok (Tulangan Sengkang)

d. Perhitungan Volume Semen, Pasir dan Kerikil

1. Kolom Praktis ukuran $11 \times 11 \mathrm{~cm}$ Lantai I

2. Kolom Praktis ukuran $11 \times 11 \mathrm{~cm}$ Lantai II

3. Pekerjaan Kolom 20/20

4. Pekerjaan Balok Pinggang ukuran $10 / 20 \mathrm{~cm}$

5. Pekerjaan Balok DAK Kubah Utama 20/40

6. Pekerjaan Balok DAK Menara 15/30

7. Pekerjaan Balok RB1 10/15

Tabel 1. Rekapitulasi Kebutuhan Material Konstruksi Di Lapangan

\begin{tabular}{ccccc}
\hline No. & Jenis Material & Jumlah Material & $\begin{array}{c}\text { Jumlah Material } \\
\text { (dibulatkan) }\end{array}$ & Satuan \\
\hline & Besi Tulangan Ø12 & 125,33 & 126 & Btg \\
1. & Besi Tulangan Ø10 & 91,63 & 92 & Btg \\
& Besi Tulangan Ø8 & 167,78 & 168 & Btg \\
\hline
\end{tabular}

Tabel 2. Rekapitulasi Kebutuhan Material Konstruksi Di Lapangan (lanjutan)

\begin{tabular}{ccccc}
\hline No. & Jenis Material & Jumlah Material & $\begin{array}{c}\text { Jumlah Material } \\
\text { (dibulatkan) }\end{array}$ & Satuan \\
\hline 2. & Semen & $2.926,27$ & 2.926 & Sak \\
3. & Pasir & 5,67 & 6 & $\mathrm{~m}^{3}$ \\
4. & Kerikil & 7,82 & 8 & $\mathrm{~m}^{3}$ \\
\hline
\end{tabular}

Sumber: Data Olahan (2019)

Tabel 3. Rekapitulasi Sisa Material Konstruksi Di Lapangan

\begin{tabular}{ccccccc}
\hline No. & Jenis Material & $\begin{array}{c}\text { Pembelian } \\
\text { Material }\end{array}$ & $\begin{array}{c}\text { Kebutuhan } \\
\text { Material }\end{array}$ & Sisa Material & $\begin{array}{c}\text { Persentase } \\
\text { Sisa } \\
\text { Material } \\
(\boldsymbol{\%})\end{array}$ & Satuan \\
\hline 1. & Besi Tulangan $\emptyset 12$ & 135 & 126 & 9 & 4,76 & $\mathrm{Btg}$ \\
& Besi Tulangan $\emptyset 10$ & 100 & 92 & 8 & 5,43 & $\mathrm{Btg}$ \\
2. & Besi Tulangan $\varnothing 8$ & 175 & 168 & 7 & 2,38 & $\mathrm{Btg}$ \\
3. & Semen & 2.935 & 2.926 & 9 & 0,07 & Sak \\
4. & Pasir & 8 & 6 & 2 & 33,33 & $\mathrm{~m}^{3}$ \\
\hline
\end{tabular}

Sumber: Data Olahan (2019)

Faktor-faktor yang menjadi penyebab terjadinya sisa material konstruksi (construction waste) pekerjaan balok dan kolom pada Kegiatan Pembangunan Mesjid Komplek Perkantoran Walikota Jambi (Lanjutan) adalah sebagai berikut:

1) Desain : Perubahan desain.

Kurangnya informasi gambar.

2) Pengadaan : Kesalahan pemesanan, kelebihan, kekurangan, dll.

Pesanan tidak dapat dilakukan dalam jumlah kecil.

3) Penanganan : Membuang atau melempar material.

Penyimpanan material yang tidak benar.

4) Residual : Sisa pemotongan material tidak dapat dipakai lagi.

Kesalahan pada saat pemotongan material. 


\section{SIMPULAN}

1. Persentase sisa material konstruksi pekerjaan balok dan kolom pada Kegiatan Pembangunan Mesjid Komplek Perkantoran Walikota Jambi (Lanjutan) terdiri dari:

a. Besi tulangan: besi $\varnothing 12$ sebanyak 4,76\%; besi $\varnothing 10$ sebanyak 5,43\% dan besi $\emptyset 8$ sebanyak 2,38\%.

b. Semen sebanyak $0,07 \%$.

c. Pasir sebanyak $33,33 \%$.

d. Kerikil sebanyak $25 \%$.

2. Persentase terbesar sisa material konstruksi pekerjaan balok dan kolom pada Kegiatan Pembangunan Mesjid Komplek Perkantoran Walikota Jambi (Lanjutan) adalah pasir, yakni sebanyak 33,33\% atau setara dengan $2 \mathrm{~m}^{3}$.

3. Beberapa faktor yang menyebabkan terjadinya sisa material konstruksi (construction waste) pekerjaan balok dan kolom pada Kegiatan Pembangunan Mesjid Komplek Perkantoran Walikota Jambi (Lanjutan) adalah sebagai berikut:
○ Desain
: Perubahan desain.
○ Pengadaan : Kesalahan pemesanan, kelebihan, kekurangan, dll.
Kurangnya informasi gambar.
Pesanan tidak dapat dilakukan dalam jumlah kecil.
○ Penanganan : Membuang atau melempar material.
- Residual : Sisa pemotongan material tidak dapat dipakai lagi.
Penyimpanan material yang tidak benar.
Kesalahan pada saat pemotongan material.

\section{DAFTAR PUSTAKA}

Al-Moghany, S. S. 2006. Managing and Minimizing Construction Waste in Gaza Strip. Gaza: The Islamic University of Gaza

Dimyati, H., Nurjaman, K. 2014. Manajemen Proyek. Cetakan Pertama. Bandung: Pustaka Setia

Ervianto, I. W. 2005. Manajemen Proyek Konstruksi. Edisi Revisi. Yogyakarta: Andi

Gavilan, R. M., L. E., Bernold. 1994. Source Evaluation of Solid Waste In Building Construction. Journal of Construction Engineering and Management

Sudarmoko. 1996. Diagram Perancangan Kolom Beton Bertulang. Yogyakarta: Jurusan Teknik Sipil, Fakultas Teknik, Universitas Gadjah Mada

Widiasanti, Irika dan Lenggogeni. 2013. Manajemen Konstruksi. Bandung: PT Remaja Rosdakarya

Wikipedia. 2016. Manajemen Konstruksi: id.wikipedia.org/wiki/Manajemen_konstruksi 